\title{
The Efficacy of Eltrombopag Treatment in Patients who developed Platelet Engraftment Failure after Allogeneic Stem Cell Transplantation: A Single Center Experience
}

\author{
Allojenik Kök Hücre Nakli Sonrası Trombosit Engrafman Yetersizliği Gelişen \\ Hastalarda Eltrombopag Tedavisinin Etkinliği: Tek Merkez Deneyimi
}

(iD Ali ESER1, id Ayşen TIMMURAĞAOĞLU22

${ }^{1}$ Bezmialem Vakıf University Faculty of Medicine, Department of Hematology, İstanbul, Turkey

${ }^{2}$ Hisar Intercontinental Hospital, Department of Stem Cell Transplantation, İstanbul, Turkey

\begin{abstract}
Objective: Persistent thrombocytopenia is a common complication of allogeneic stem cell transplantation (ASCT). Treatment of platelet engraftment failure after ASCT remains controversial. Drugs, such as eltrombopag, are used for this purpose. Eltrombopag is an Food and Drug Administration -approved oral thrombopoietin receptor agonist. We aim to present the results of 12 patients treated with eltrombopag in our center for severe thrombocytopenia after ASCT.

Methods: From January 2018 to February 2020, a total of 56 patients underwent ASCT. Twelve patients had persistent thrombocytopenia following ASCT. All patients received eltrombopag.

Results: Primary platelet engraftment failure developed in six of 12 patients who developed persistent thrombocytopenia after ASCT. Secondary platelet engraftment failure developed in six of them. After eltrombopag treatment, eight (66.7\%) patients achieved transfusion independence, whereas four patients $(33.3 \%)$ could not. The maximum platelet count after the eltrombopag treatment was median 118.000 (range: $24,000-253,000) / \mu \mathrm{L}$. The median time from the start of eltrombopag until the platelet count was $>50,000$ / $\mu \mathrm{L}$ was 18 (range: 14-112) days. The median duration of treatment with eltrombopag was 70 (range: 26-180) days. Eltrombopag was discontinued in all patients who survived and had full platelet recovery.
\end{abstract}

\begin{abstract}
ÖZ
Amaç: Kalıcı trombositopeni, allojenik kök hücre transplantasyonunun (AKHN) yaygin komplikasyonlarından biridir. AKHN sonrası trombosit engrafman yetersizliğinin tedavisi hala tartışmalıdır. Eltrombopag bu amaçla kullanılan ilaçlardan biridir. Eltrombopag, FDA onaylı oral trombopoietin reseptör agonistidir. AKHN sonrası şiddetli trombositopeni nedeniyle merkezimizde eltrombopag ile tedavi edilen 12 hastanın sonuçlarını ortaya koymayı amaçladık.

Yöntemler: Kök hücre nakil merkezimizde ocak 2018'den şubat 2020 'ye kadar 56 hastaya AKHN yapildı. Oniki hastada AKHN sonrası kalıcı trombositopeni gelişti. Tüm hastalar eltrombopag aldı.

Bulgular: AKHN sonrası inatçı trombositopeni gelişen 12 hastanın altısında birincil trombosit engrafman yetersizliği, altısında ise ikincil trombosit engrafman yetersizliği gelişti. Eltrombopag tedavisi sonrası sekiz hasta $(\% 66,7)$ transfüzyon bağımsızlığına ulaşılırken dört hastada $(\% 33,3)$ ulaşılamadı. Eltrombopag tedavisinden sonra maksimum trombosit sayısı medyan 118.000 (aralık: 24.000$253,000) / \mu \mathrm{L}$ oldu. Eltrombopag başlangıcından trombosit sayısı $>50.000 / \mu \mathrm{L}$ olana kadar geçen süre medyan 18 (aralık:14-112) gün idi. Eltrombopag ile medyan tedavi süresi 70 (aralık: 26-180) gün oldu. Yaşayan ve tam trombosit iyileşmesi olan tüm hastalarda eltrombopag kesildi.
\end{abstract}

Address for Correspondence: Ali ESER, Bezmialem Vakıf University Faculty of Medicine, Department of Hematology, İstanbul, Turkey

E-mail: dralieser@gmail.com ORCID ID: orcid.org/0000-0001-9423-928X

Cite this article as: Eser A, Timurağaoğlu A. The Efficacy of Eltrombopag Treatment in Patients who developed Platelet Engraftment Failure after Allogeneic Stem Cell Transplantation: A Single Center Experience . Bezmialem Science 2021;9(1):98-105.

๑) Copyright 2021 by the Bezmiâlem Vakıf University

Bezmiâlem Science published by Galenos Publishing House.
Received: 14.11.2020

Accepted: 22.12.2020 
Conclusion: Thrombocytopenia after ASCT is a condition that should be treated as it can lead to life-threatening bleeding.

Keywords: Hematopoietic stem cell transplantation, platelet engraftment failure, eltrombopag
Sonuç: AKHN sonrası kalıcı trombositopeni, yaşamı tehdit eden kanamalara yol açabileceği için tedavi edilmesi gereken bir durumdur.

Anahtar Sözcükler: Allojenik kök hücre nakli, trombosit engrafman yetersizliği, eltrombopag

\section{Introduction}

Persistent thrombocytopenia is a common complication of allogeneic stem cell transplantation (ASCT) (1). Its causes are not well understood. Poor graft function, viral infections such as cytomegalovirus (CMV), impaired platelet production due to side effects of immunosuppressive or antiviral drugs, increased destruction associated with infection and immune-mediated processes, or a combination of these mechanisms may play a role (2). A platelet count $>20,000 / \mu \mathrm{L}$ for three days after transplantation is considered platelet engraftment. There are two forms of thrombocytopenia after ASCT. Primary platelet engraftment failure is characterized by the absence of initial donor cell engraftment (donor cells less than 95\%); peripheral blood platelet count $<20 \times 10^{9} / \mathrm{L}$ by day +28 after allo-HSCT from peripheral blood or bone marrow progenitors in the absence of relapse (3). It is seen in 5\%-20\% of transplantations. If the posttransplant platelet count reaches $50,000 / \mu \mathrm{L}$ and then persistently decreases to $<20,000 / \mu \mathrm{L}$, it is called secondary platelet engraftment failure (SPEF). Its prevalence is around $20 \%$ (4).

There is evidence which is proving that eltrombopag can induce hematopoiesis with a non-competitive activation of c-MPL. In immune thrombocytopenia, TPO levels are at the upper or near the upper limit of the mean, while they increase significantly in aplastic anemia (5).

Romiplostim and eltrombopag, which are FDA-approved thrombopoietin receptor agonists, stimulate platelet production, especially in immune thrombocytopenia $(6,7)$. The efficacy and safety of eltrombopag have been demonstrated in a study by Wong et al. (8) in immune thrombocytopenic purpura (ITP) and a study by Townsley et al. (9) severe aplastic anemia. Given the similarity between severe aplastic anemia and graft failure, it was suggested that eltrombopag therapy could also be successful in graft failure (10). Recently, several articles with small numbers of cases showing the efficacy of eltrombopag in persistent thrombocytopenia developed after HSCT have been published (11-13).

Herein we reported the results of 12 patients treated with eltrombopag in our center with severe thrombocytopenia after HSCT retrospectively.

\section{Method}

From January 2018 to February 2020, 119 patients had hematopoietic stem cell transplantation in our center's bone marrow transplantation unit. Fifty-six patients underwent
ASCT, and 12 of them developed persistent thrombocytopenia. Our study was approved by the Bezmialem Vakıf University ethics committee.

Endpoint: The endpoints were determined as platelet levels $>50,000 / \mu \mathrm{L}$ after initiating treatment with eltrombopag either permanently after cessation of drug or need to continue therapy and no response after four months therapy at a dose of $150 \mathrm{mg} /$ day.

\section{Eltrombopag Treatment}

Eltrombopag was initiated at a dose of $50 \mathrm{mg} /$ day in seven patients. The eltrombopag dose was increased by $50 \mathrm{mg}$ weekly to attain a final dose of $150 \mathrm{mg} /$ day. Due to the lack of platelet response in patients who received a daily dose below $150 \mathrm{mg}$, three patients were started with $100 \mathrm{mg}$, and two patients were directly started at $150 \mathrm{mg} /$ day. Eltrombopag was given to all patients with a maximum dose of $150 \mathrm{mg}$. After the platelet count exceeded $150,000 / \mu \mathrm{L}$, it was planned to taper first by decreasing $50 \mathrm{mg}$ and $25 \mathrm{mg}$. When a decrease in platelet count was also detected during the cessation period, the dose was increased to the previous dose again. Platelet transfusions were performed when the platelet count was $<15,000 / \mu \mathrm{L}$ in clinically stable patients and had no fever and bleeding symptoms and in patients with signs of bleeding, even if the platelet count was between $20,000 / \mu \mathrm{L}$ and $50,000 / \mu \mathrm{L}$.

\section{Statistical Analysis}

Average values, standard deviation, median lowest, highest values, frequency, and ratio values were used in the descriptive statistics. The distribution of the variables was checked by the Kolmogorov-Smirnov test. The Wilcoxon test was used to analyze quantitative dependent data. The SPSS 22.0 program was used for the analyses. The Kaplan-Meier method was used for survival analysis.

\section{Results}

In a total of 12 patients who developed persistent thrombocytopenia after ASCT, 10 were men, and two were women. The median age was 40.5 (range: 19-67) years. Platelet engraftment failure was observed in 12 out of 56 patients $(21.4 \%)$. The diagnoses of these patients were acute lymphoblastic leukemia ( $n=3 ; 25 \%)$, acute myeloid leukemia ( $\mathrm{n}=6 ; 50 \%)$, Hodgkin lymphoma (HL, $\mathrm{n}=1$; $8.3 \%$ ), myelodysplastic syndrome (MDS, $n=1 ; 8.3 \%$ ) and nonHL (NHL, $\mathrm{n}=1 ; 8.3 \%$ ). Nine patients had ASCT from a sibling donor (one of which was haploidentical), and three patients from an unrelated donor. Nine of the donors were a full match, two donors had one mismatch, and one donor had two mismatches 
peripheral stem cell source, and myeloablative regimens were used in all patients. The median given stem cell number was 6.65 $(4.7-9.3) \times 10^{6} / \mathrm{kg}$. Neutrophil engraftment could be achieved in all patients. The median time to neutrophil engraftment was 20 (9-27) days). Six patients developed PPEF, and the SPEF occurred in the other six patients. Cyclophosphamide was used in four patients after transplantation. Transfusion independence was achieved in three of these patients. Patient-donor blood groups were the same in seven patients and different in five patients. Before eltrombopag, the frequency for transfusion was once a week in two patients, 1-2 times a week in seven patients, and more than two times a week in three patients. A decreased number of megakaryocytes in the bone marrow were seen in six patients, whereas it was normal in the other six patients. The median time from transplant to eltrombopag initiation was 69 (range: 48-128) days. After eltrombopag treatment, eight patients achieved transfusion independence. The median platelet count four months after the start of eltrombopag treatment was 118.000 (range: $24,000-253,000) / \mu \mathrm{L}$. The median time for the platelet count to reach $50,000 / \mu \mathrm{L}$ was 18 (range: $14-112$ ) days. The median duration of treatment with eltrombopag was 70 (range: 26-180) days. Currently, five of these patients are alive, and seven died due to septicemia. Eltrombopag treatment was discontinued in all patients who survived and had full platelet recovery. Patient characteristics are summarized in Table 1.

The patients' response rates were evaluated according to their status before eltrombopag are summarized in Table 2.

The duration of achieving transfusion independence in responders was 61.9 days (36.4-87.3)(Figure 1).

The duration of achieving transfusion independence in patients who had one or fewer transfusions per week before eltrombopag was significantly shorter than those with two or more platelet needs before eltrombopag [ 46.5 and 83.4 days (HR: $0.255,95 \%$ CI: $0.050-1.29, \mathrm{p}=0.045$ ] (Figure 2).

In the group whose patient-donor blood group was compatible [34.1 and 86.1 days HR: 5.071, 95\% CI, $\mathrm{p}=0.040$ ], the time to achieve transfusion independence was significantly shorter than the group without blood group compatibility (Figure 3).

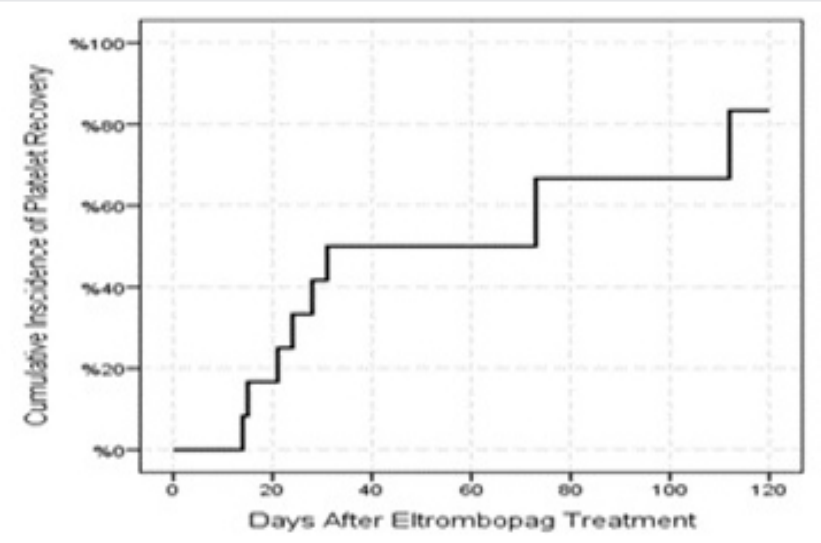

Figure 1. Cumulative transfusion independence
There was no significant difference regarding the time to achieve transfusion independence in primary and secondary failure. The time to achieve transfusion independence in patients who had a normal megakaryocyte count in their bone marrow was significantly shorter than those who had a low megakaryocyte count [85.0-38.8 days, HR: 3.667, 95\% CI 0.698-19.25, $\mathrm{p}=0.045]$ (Figure 4).

The duration of achieving transfusion independence in the group using posttransplant cyclophosphamide (47.7 and 68.7 days, $\mathrm{p}>0.05$ ) did not differ from the group that did not use cyclophosphamide (Figure 5).

The transfusion frequency decreased in three of four patients who did not respond to eltrombopag therapy. According to our study, a dose of eltrombopag $<150 \mathrm{mg} /$ day was not effective.

In the last outpatient visit, the median number of platelets was 80.500 (range: $19,000-210,000) / \mu \mathrm{L}$ and was statistically significant (Table 3) (Figure 6).

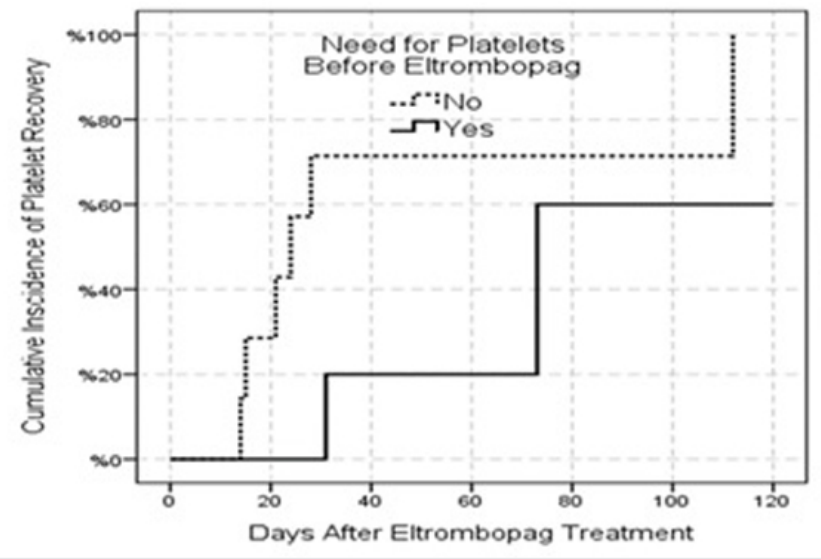

Figure 2. Need for platelets before eltrombopag

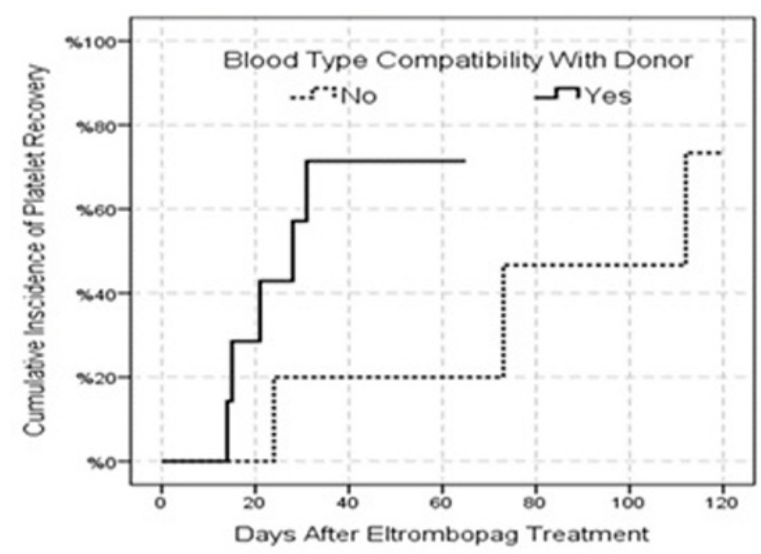

Figure 3. Patient-donor blood group compatibility 
Table 1. Patient characteristics

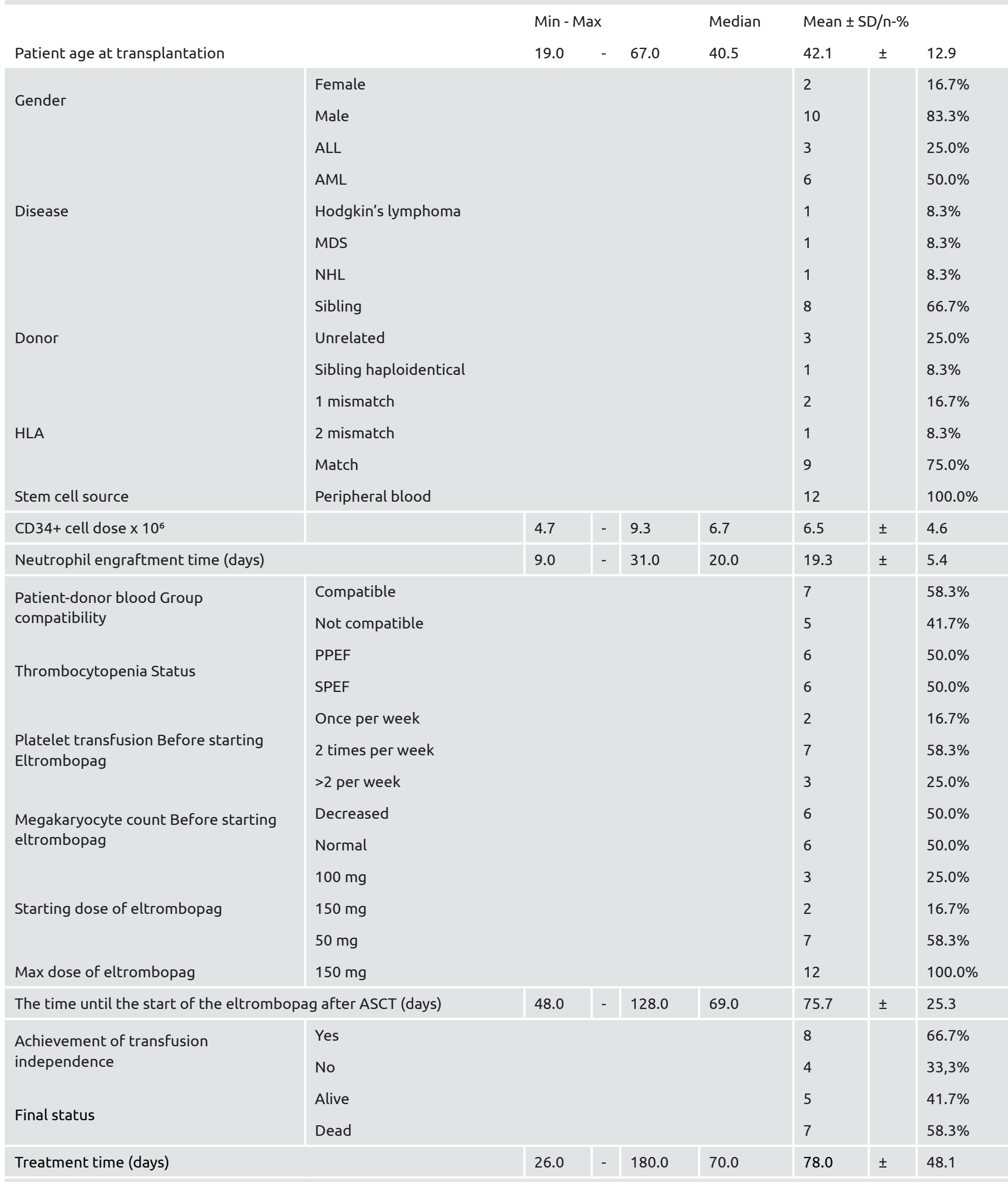

ALL: Acute lymphoblastic leukemia, AML: Acute myeloid leukemia, MDS: Myelodysplasticsydrome, NHL: non-Hodgkin lymphoma, HLA: Human leucocyte antigen, PPEF: Primary platelet engraftment failure, SPEF: Secondary platelet engraftment failure, ASCT: Allogeneic stem cell transplantation, SD: Standard deviation, Min: Minimum, Max: Maximum 


\begin{tabular}{|c|c|c|c|c|c|c|c|c|c|}
\hline \multirow[b]{3}{*}{ Age } & & \multicolumn{4}{|c|}{ Transfusion independence (-) } & \multicolumn{4}{|c|}{ Transfusion independence (+) } \\
\hline & & \multicolumn{3}{|c|}{ Mean $\pm S D / n-\%$} & \multirow{2}{*}{$\begin{array}{l}\text { Median } \\
51.5\end{array}$} & \multicolumn{3}{|c|}{ Mean $\pm S D / n-\%$} & \multirow{2}{*}{$\begin{array}{l}\text { Median } \\
39.5\end{array}$} \\
\hline & & 47.3 & \pm & 11.0 & & 39.5 & \pm & 13.7 & \\
\hline \multirow{2}{*}{ Gender } & Female & 0 & & $0.0 \%$ & & 2 & & $25.0 \%$ & \\
\hline & Male & 4 & & $100.0 \%$ & & 6 & & $75.0 \%$ & \\
\hline \multirow{2}{*}{$\begin{array}{l}\text { Patient-donor blood } \\
\text { group compatibility }\end{array}$} & Compatible & 2 & & $50.0 \%$ & & 3 & & $37.5 \%$ & \\
\hline & Not compatible & 2 & & $50.0 \%$ & & 5 & & $62.5 \%$ & \\
\hline \multirow{2}{*}{ Thrombocytopenia status } & PPEF & 2 & & $50.0 \%$ & & 4 & & $50.0 \%$ & \\
\hline & SPEF & 2 & & $50.0 \%$ & & 4 & & $50.0 \%$ & \\
\hline \multirow{2}{*}{$\begin{array}{l}\text { Platelet transfusion } \\
\text { before starting } \\
\text { eltrombopag }\end{array}$} & $(-)$ & 1 & & $25.0 \%$ & & 6 & & $75.0 \%$ & \\
\hline & $(+)$ & 3 & & $75.0 \%$ & & 2 & & $25.0 \%$ & \\
\hline \multicolumn{2}{|c|}{ Platelet count before starting eltrombopag } & 14,000 & \pm & 4,243 & 15,000 & 20,000 & \pm & 6,866 & 21,500 \\
\hline \multicolumn{2}{|c|}{ Max platelet count after eltrombopag } & 39,000 & \pm & 11,165 & 42,000 & 16,5125 & \pm & 54,186 & 166,000 \\
\hline \multicolumn{2}{|c|}{$\begin{array}{l}\text { Days from starting eltrombopag to platelet } \\
50.000 / \mu \mathrm{L}\end{array}$} & & & & & 26.5 & \pm & 33.9 & 18.0 \\
\hline
\end{tabular}

PPEF: Primary platelet engraftment failure, SPEF: Secondary platelet engraftment failure, SD: Standard deviation

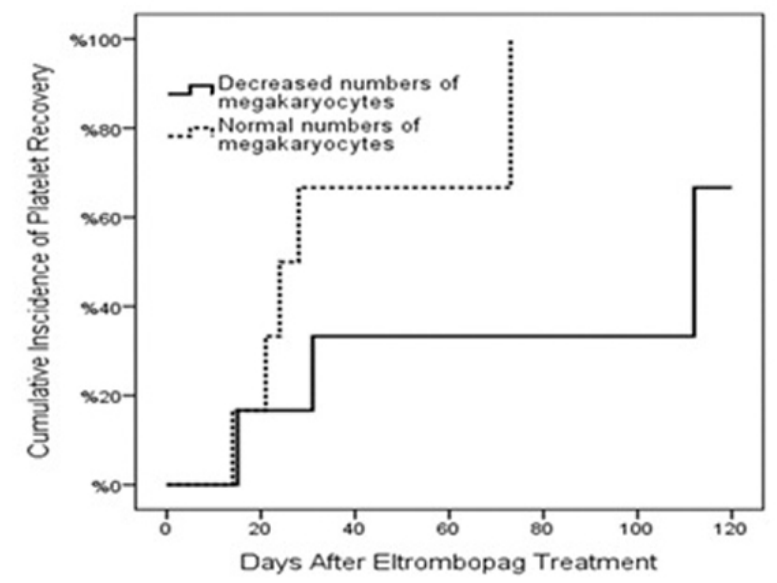

Figure 4. Megakaryocyte counts before starting eltrombopag

\section{Discussion}

Engraftment failure after ASCT has been a life-threatening complication with a rate of 5\%-27\% (14-16). After hematopoietic stem cell transplantation, two types of engraftment failure can be observed: PPEF and SPEF $(3,4)$. Various methods have been tried to activate engraftment. These are growth factors, CD34+ stem cell enhancement, mesenchymal stem cells, and a second ASCT (16-19). However, none of these methods was completely effective. Eltrombopag, a thrombopoietin receptor agonist, has recently been started to be used.

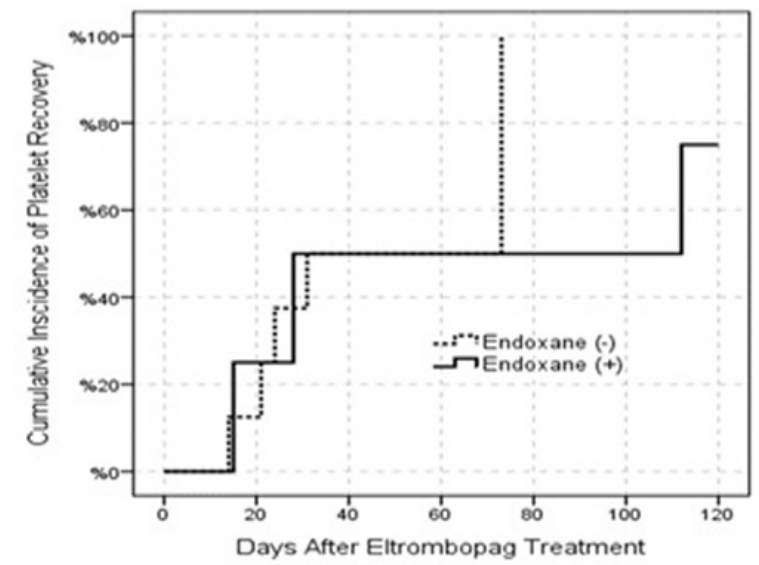

Figure 5. Using cyclophosphamide after ASCT ASCT: Allogeneic stem cell transplantation

In this article, we wanted to share our experience with eltrombopag in a patient who developed thrombocytopenia after ASCT. In our ASCT patients, platelet engraftment failure was found to be $21.4 \%$. Eltrombopag treatment provided transfusion independence in $66.7 \%$ of patients and it was discontinued in all living patients. The dose was increased to $150 \mathrm{mg}$ /day in all patients.

Bielski et al. reported that the post-ASCT PPEF prevalence was $3 \%$ (3). In three separate reports, two of four patients reported as PPEF were treated with romiplostim and the other two were treated with eltrombopag. Transfusion independence was 
Informed Consent: Patient consent was not obtained because the study was retrospective.

Peer-review: Externally peer reviewed.

\section{Authorship Contributions}

Surgical and Medical Practices: A.E., A.T.A., Concept: A.E., Design: A.E., Data Collection or Processing: A.E., Analysis or Interpretation: A.T.A., Literature Search: A.E., Writing: A.E

Conflict of Interest: No conflict of interest was declared by the authors.

Financial Disclosure: The authors declared that this study received no financial support.

\section{References}

1. Kuzmina Z, Eder S, Bohm A, Pernicka E, Vormittag L, Kalhs P. et al. Significantly worse survival of patients with NIH-defined chronic graft-versus-host disease and thrombocytope- nia or progressive onset type: results of a prospective study. Leukemia 2012;26:746-56.

2. Yamazaki R, Kuwana M, Mori T, Okazaki Y, Kawakami Y, Ikeda Y, et al. Prolonged thrombocytopenia after allogeneic hematopoietic stem cell transplantation: associations with impaired platelet production and increased platelet turnover. Bone Marrow Transplant 2006;38:377-84.

3. Bielski M, Yomtovian R, Lazarus HM, Rosenthal N. Prolonged isolated thrombocytopenia after hematopoietic stem cell transplantation: mor- phologic correlation. Bone Marrow Transplant 1998;22:1071-6.

4. Bruno B, Gooley T, Sullivan KM, Davis C, Bensinger WI, Storb R, et al. Secondary failure of platelet recovery after hematopoietic stem cell transplantation. Biol Blood Marrow Transplant 2001;7:154-62.

5. Emmons RV, Reid DM, Cohen RL, Meng G,_Young NS, Dunbar CE, et al. Human thrombopoietin levels are high when thrombocytopenia is due to megakaryocyte deficiency and low when due to increased platelet destruction. Blood 1996;87:406871.

6. Bussel JB, Kuter DJ, Pullarkat V, Lyons RM, Guo M, Nichol JL. Safety and efficacy of long-term treatment with romiplostim in thrombocytopenic patients with chronic ITP. Blood 2009; 113:216171.

7. Bussel JB, Cheng G, Saleh MN, Psaila B, Kovaleva L, Meddeb B, et al. Eltrombopag for the treatment of chronic idiopathic thrombocytopenic purpura. N Engl J Med 2007;357:2237-47.

8. Wong RSM, Saleh MN, Khelif A, Salama A, Portella MSO, Burgess P, et al. Safety and efficacy of long-term treatment of chronic/persistent ITP with eltrombopag: final results of the EXTEND study. Blood 2017;130:2527-36.

9. Townsley DM, Scheinberg P, Winkler T, Desmond R, Dumitriu B, Rios $\mathrm{O}$, et al. Eltrombopag added to standard immunosuppression for aplastic anemia. N Engl J Med 2017;376:1540-50.

10. Yuan C, Boyd AM, Nelson J, Patel RD, Varela JC, Goldstein SC, et al. Eltrombopag for Treating Thrombocytopenia after Allogeneic Stem Cell Transplantation. Biol Blood Marrow Transplant 2019;25:1320-4.
11. Tang C, Chen F, Kong D, Ma Q, Dai H, Yin J, et al. Successful treatment of secondary poor graft function post allogeneic hematopoietic stem cell transplantation with eltrombopag. J Hematol Oncol 2018;11:103.

12. Tanaka T, Inamoto Y, Yamashita T, Shigeo F, Okinaka K, Kurosawa $S$, et al. Eltrombopag for Treatment of Thorombocytopenia after Allogeneic Hematopoietic Cell Transplantation. Biol Blood Marrow Transplant 2016;22:919-24.

13. Bento L, Bastida JM, Garcia I, Garcia E, Rivera D, Bosch A, et al. Thrombopoietin Receptor Agonist for Severe Thrombocytopenia after Allogeneic Stem Cell Transplantation: Experience of the Spanish Group of Hematopoietic Stem Cell Transplantation. Biol Blood Marrow Transplant 2019;25:1825-31.

14. Lee KH, Lee JH, Choi SJ, Lee JH, Kim S, Seol M, et al. Failure of trilineage blood cell reconstitution after initial neutrophil engraftment in patients undergoing allogeneic hematopoietic cell transplantation frequency and outcomes. Bone Marrow Transplant 2004;33:729-34.

15. Woolfrey A, Anasetti C. Allogeneic hematopoietic stem-cell engraftment and graft failure. Pediatr Transplant 1999;3(Suppl $1): 35-40$.

16. Bittencourt H, Rocha V, Filion A, Ionescu I, Herr AL, Garnier F, et al. Granulocyte colony-stimulating factor for poor graft function after allogeneic stem cell transplantation: 3 days of G-CSF identifies long-term responders. Bone Marrow Transplant 2005;36:431-5.

17. Ghobadi A, Fiala MA, Ramsingh G, Gao F, Abboud CN, StockerlGoldstein K, et al. Fresh or cryopreserved CD34(+)-selected mobilized peripheral blood stem and progenitor cells for the treatment of poor graft function after allogeneic hematopoietic cell transplantation. Biol Blood Marrow Transplant 2017;23:1072-7.

18. Liu X, Wu M, Peng Y, Chen X, Sun J, Huang F, et al. Improvement in poor graft function after allogeneic hematopoietic stem cell transplantation upon administration of mesenchymal stem cells from third-party donors: a pilot prospective study. Cell Transplant 2014;23:1087-98.

19. Guardiola P, Kuentz M, Garban F, Blaise D, Reiffers J, Attal M, et al. Second early allogeneic stem cell transplantations for graft failure in acute leukaemia, chronic myeloid leukaemia and aplastic anaemia. French Society of Bone Marrow Transplantation. Br J Haematol 2000;111:292-302.

20. Poon LM, Di Stasi A, Popat U, Champlin RE, Ciurea SO. Romiplostim for delayed platelet recovery and secondary thrombocytopenia following allogeneic stem cell transplantation. Am J Blood Res 2013;3:260-4.

21. Reid R, Bennett JM, Becker M, Chen Y, Milner L, Phillips GL, et al. Use of eltrombopag, a thrombopoietin receptor agonist, in posttransplantation thrombocytopenia.Am J Hematol 2012;87:743-5.

22. Fujimi A, Kamihara Y, Hashimoto A, Kanisava Y, Nakajima C, Hayasaka $\mathrm{N}$ et al. Identification of anti-thrombopoietin receptor antibody in prolonged thrombocytopenia after allogeneic hematopoietic stem cell transplantation treated successfull with eltrombopag. Int J Hematol 2015;102:471-6.

23. Beck JC, Burke MJ, Tolar J. Response of refractory immune thrombocytopenia after bone marrow transplantation to romiplostim. Pediatr Blood Cancer 2010;54:490-1. 
24. Calmettes C, Vigouroux S, Tabrizi R, Milpied N. Romiplostim (AMG531, Nplate) for secondary failure of platelet recovery after allo-SCT. Bone Marrow Transplant 2011;46:1587-9.

25. Bollag RJ, Sterett M, Reding MT, Key NS, Cohn CS, Ustun C. Response of complex immune-mediated thrombocytopenia to romiplostim in the setting of allogeneic stem cell transplantation for chronic myelogenous leukemia. Eur J Haematol 2012;89:361-4.

26. DeRemer DL, Katsanevas K, Bradley A, Awan FT. Romiplostim resistance in secondary failure of platelet recovery. J Oncol Pharm Pract 2013;19:369-72.

27. Maximova N, Zanon D, Rovere F, Maestro A, Schillani G, Paparazzo R. Romiplostim for secondary thrombocytopenia following allogeneic stem cell transplantation in children. Int J Hematol 2015;102:62632.
28. Battipaglia G, Ruggeri A, Brissot E, Mamez AC, Malard F, Belhocine $\mathrm{R}$, et al. Safety and feasibility of romiplostim treatment for patients with persistent thrombocytopenia after allogeneic stem cell transplantation. Bone Marrow Transplant 2015;50:1574-7.

29. Cheng G, Saleh MN, Marcher C, Vasey S, Mayer B, Aivado $\mathrm{M}$, et al. Eltrombopag for management of chronic immune thrombocytopenia (RAISE): a 6-month, randomised, phase 3 study. Lancet 2011;377:393-402.

30. Will B, Kawahara M, Luciano JP, Bruns I, Parekh S, Erickson-Miller $\mathrm{CL}$, et al. Effect of the nonpeptide thrombopoietin receptor agonist Eltrombopag on bone marrow cells from patients with acute myeloid leukemia and myelodysplastic syndrome. Blood 2009;114:3899-908. 